\title{
Analysis of Photovoltaic Cells Performance at University of Bangka Belitung
}

\author{
Andi Maulana ${ }^{1}$, Welly Yandi ${ }^{1}$, Wahri Sunanda ${ }^{1, *}$ \\ ${ }^{I}$ Department of Electrical Engineering, Universitas Bangka Belitung, Bangka, Indonesia \\ *Corresponding Author: sunandawahri@gmail.com
}

Article history

Received: 26.07.2020

Revised: 22.08.2020

Accepted: 23.09.2020

DOI:10.31629/jit.v1i2.3166

\begin{abstract}
Photovoltaic as a renewable source of electrical energy is utilized at University of Bangka Belitung (UBB) as a source of additional electrical energy. With a capacity of $280 \mathrm{Wp}$ per unit, the photovoltaic performance needs to be maintained so that their performance is getting better. After cleaning with cleaning fluid, the photovoltaic voltage output has increased from $13.7-16.8$ volt to 17.4 - 22.6 volt. After cleaning the photovoltaic, the current output also increased from $0.33-1.8 \mathrm{~A}$ to $1.5-7.6 \mathrm{~A}$. The real power generated also increased from 4.5 - 29.7 Watt to 26 - 164 Watt.
\end{abstract}

Keywords: photovoltaic, voltage, current, real power

\section{Introduction}

University of Bangka Belitung is currently supplied by electricity sourced from PLN with a total power supply of $690 \mathrm{kVA}$ [1]. The availability of electrical energy is to supply all existing facilities and infrastructure at Universitas Bangka Belitung. In the framework of developing green energy at Universitas Bangka Belitung, photovoltaics are also available as a backup electricity supply. The number of photovoltaics currently available is 680 units, with each panel powering $280 \mathrm{Wp}$, as can be seen in figure 1.

Several buildings, campuses, and public facilities that have used photovoltaics or as a source of electrical energy include Kayubihi, Bangli [2], Department of Electrical Engineering, Universitas Brawijaya [3], one of the villages in Banjarnegara district [4]

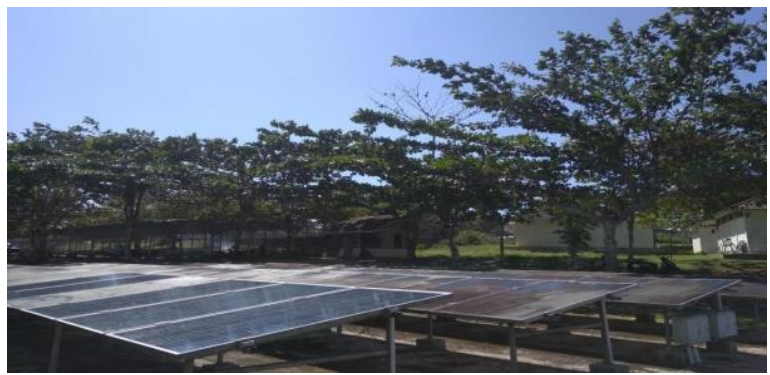

Figure 1. Photovoltaic at Universitas Bangka Belitung

However, the existence of photovoltaics needs attention for treatment. Because over time, various solid materials that stick to the surface of the photovoltaic can cause the performance of the solar panel to decrease, so various methods are applied so that the performance of the photovoltaic can increase with good efficiency [5] - [11]. 
In this study, a comparison of photovoltaics' performance will be carried out before and after cleaning with cleaning fluid. Several parameters will be used as an indicator of the performance of the photovoltaics, where 1 (one) unit has a capacity of $280 \mathrm{Wp}$. This will be a recommendation to improve the performance of 680 photovoltaic units at Bangka Belitung University as a source of backup electrical energy and support the use of new and renewable energy to reduce carbon emissions.

\section{Materials and Methods}

1. The parameters measured are voltage, current, and output power on the solar panel using an energy meter as a measuring tool and using a battery as a load to be able to measure the output current of the photovoltaic as in figure 2 .

2. To measure the value of solar radiation using a solar power meter is carried out at the same time.

3. Measurements were taken by taking data every 30 minutes on the photovoltaics, before and after cleaning, as seen in figure 3 .

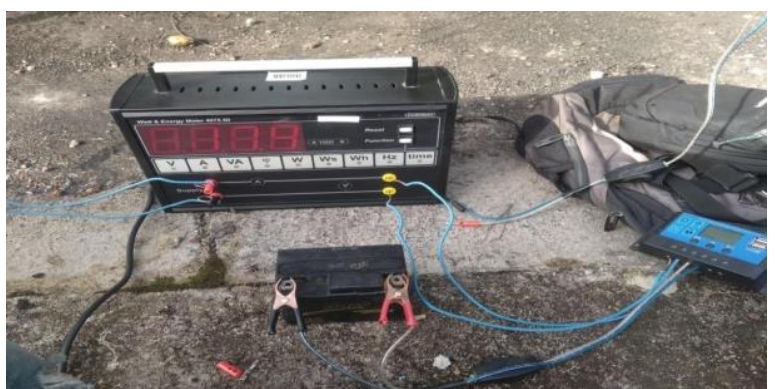

Figure 2. Measurement of voltage, current, and real power

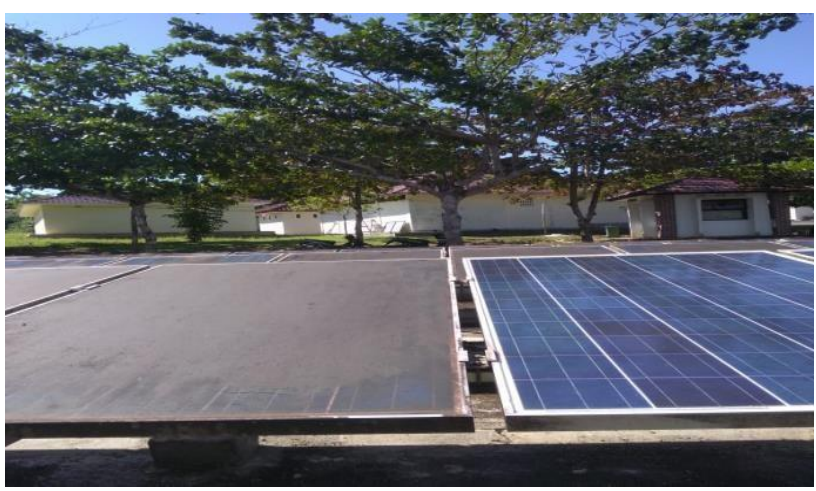

Figure 3. Measurements of photovoltaic before and after cleaning

\section{Results and Discussions}

In table 1 shows measurements of solar radiation in the Bangka Belitung University environment, which are measured directly from 06.30 A.M to 06.00 P.M.

Table 1. Solar Irradiance at Universitas Bangka Belitung

\begin{tabular}{cc}
\hline $\begin{array}{c}\text { Time } \\
\text { (A.M/P.M })\end{array}$ & $\begin{array}{c}\text { Solar Irradiance } \\
\left(\mathrm{W} / \mathrm{m}^{2}\right)\end{array}$ \\
\hline $6: 30$ & 176.8 \\
\hline $7: 00$ & 180.1 \\
\hline $7: 30$ & 181.2 \\
\hline $8: 00$ & 197.5 \\
\hline $8: 30$ & 244.6 \\
\hline $9: 00$ & 339.4 \\
\hline $9: 30$ & 370.4 \\
\hline $10: 00$ & 410 \\
\hline $10: 30$ & 653.7 \\
\hline $11: 00$ & 970.3 \\
\hline $11: 30$ & 1093 \\
\hline $12: 00$ & 1131 \\
\hline $01: 30$ & 1207 \\
\hline $01: 00$ & 1231 \\
\hline $01: 30$ & 1284 \\
\hline $02: 00$ & 967.7 \\
\hline $02: 30$ & 773.6 \\
\hline $03: 00$ & 657.8 \\
\hline $03: 30$ & 538.4 \\
\hline $04: 00$ & 324.9 \\
\hline $04: 30$ & 267 \\
\hline $05: 00$ & 179.5 \\
\hline $05: 30$ & 144.9 \\
\hline $06: 00$ & 140.4 \\
\hline & \\
\hline & \\
\hline & \\
\hline & \\
\hline & \\
\hline
\end{tabular}

In figure 4 is the output measurement data from the photovoltaic before and after cleaning. In the conditions, before it was cleaned, the voltage output from the photovoltaic was around 13.7 - 16.8 volts. While in the cleaned condition, the output voltage of the photovoltaic is at $17.4-22.6$ volts. While on the photovoltaic nameplate, the maximum output voltage is 36.1 volts. 


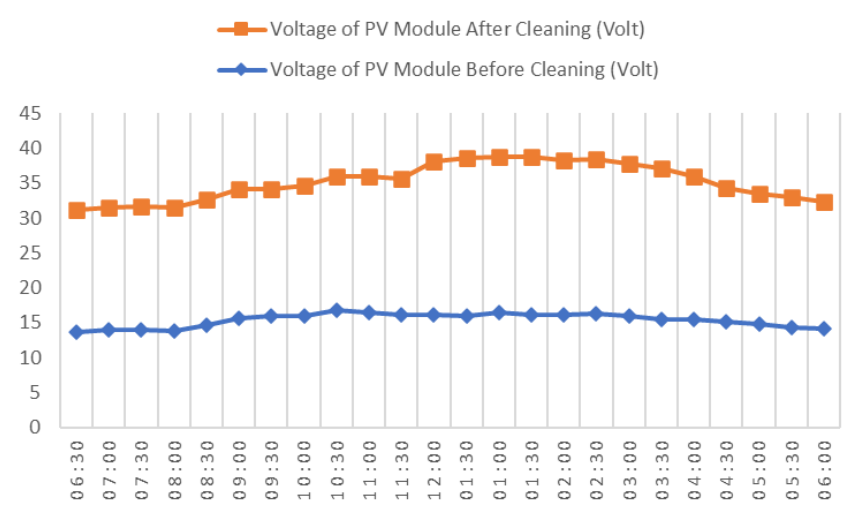

Figure 4. The voltage output of photovoltaic

Figure 5 is the current output measurement data from the photovoltaic before and after cleaning. The current output from photovoltaic ranges from 0.33 $1.8 \mathrm{~A}$ in the condition before it is cleaned. Whereas in the cleaned conditions, the current output of photovoltaic is at $1.5-7.6 \mathrm{~A}$. While on the photovoltaic nameplate, the output current maximum is $7.76 \mathrm{~A}$

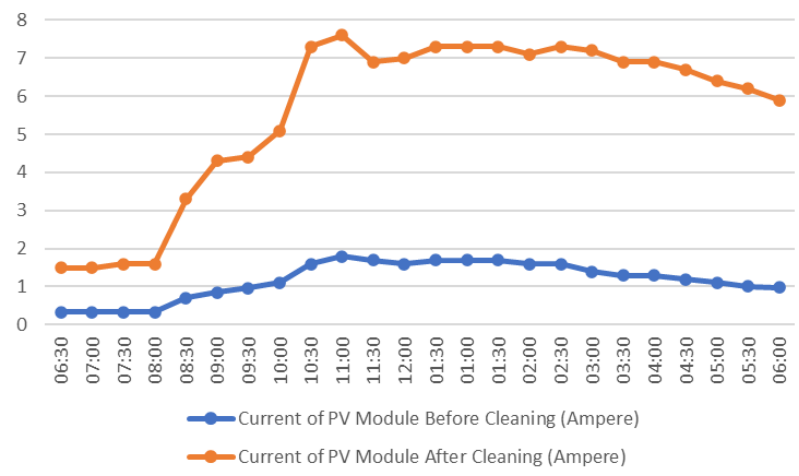

Figure 5. Current output from photovoltaic

Meanwhile, figure 6 shows the real power measurement data from photovoltaic before and after cleaning. In the pre-cleaning condition, real power from the photovoltaic is around $4.5-29.7$ Watt. Meanwhile, in the cleaned condition, real power from photovoltaic is at $26-164 \mathrm{Watt}$. While on the nameplate, the maximum power of photovoltaic is $280 \mathrm{~W}$.

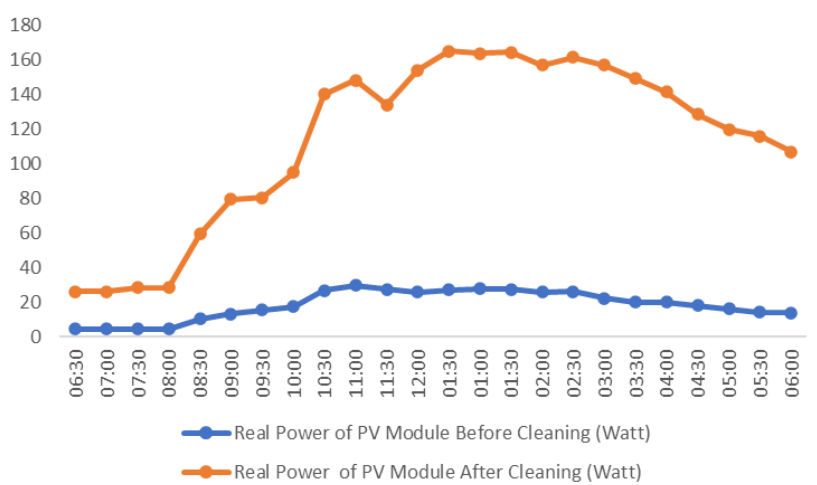

Figure 6. Real power from photovoltaic

\section{Conclusion}

After cleaning with cleaning fluid, the performance of the solar panels has increased the voltage output from 13.7 - 16.8 volts to 17.4 - 22.6 volts. For the current output from $0.33-1.8$ A before cleaning to $1.5-7.6 \mathrm{~A}$. The power generated from the solar panels has also increased from $4.5-29.7$ Watt to 26 - 164 Watt.

\section{References}

[1] W. Sunanda. 2017. Profil Beban pada Sistem Kelistrikan Universitas Bangka Belitung. Jurnal Ecotipe (Electronic, Control, Telecommunication, Information, and Power Engineering). Vol. 4 (1). pp. $1-6$.

[2] I. K. A. Setiawan, I. N. S. Kumara, I W. Sukerayasa. 2014. Analisis Unjuk Kerja Pembangkit Listrik Tenaga Surya (Plts) Satu MWP Terinterkoneksi Jaringan di Kayubihi, Bangli. Majalah Ilmiah Teknologi Elektro, Vol. 13 (1).

[3] M. Rif'an, S.H Pramono, M. Shidiq, R. Yuwono, H. Suyono, F. Suhartati, F. 2012. Optimasi pemanfaatan energi listrik tenaga matahari di jurusan teknik elektro Universitas Brawijaya. Jurnal EECCIS, Vol. 6(1), pp. 44-48.

[4] B. Winardi, A. Nugroho, A., E. Dolphina. 2019. Perencanaan Dan Analisis Ekonomi Pembangkit Listrik Tenaga Surya (PLTS) Terpusat Untuk Desa Mandiri. Jurnal Tekno, Vol. 16(2), pp. 1-11.

[5] A. Ndiaye, C. M. F. Kébé, P. A Ndiaye, A. Charki, A. Kobi, V . Sambou. 2013. Impact of dust on the photovoltaic (PV) modules characteristics after an exposition year in Sahelian environment: The case of Senegal. International Journal of Physical Sciences, 8(21), pp. 1166-1173. 
[6] M. G .Hudedmani, G. Joshi, Umayal R. M., A.Revankar. 2017. A comparative study of dust cleaning methods for the solar PV panels. Advanced Journal of Graduate Research, 1(1), pp.24-29.

[7] V. S. Saravanan, S. K Darvekar. 2018. Solar Photovoltaic panels cleaning methods: A Review. Int. J. Pure Appl. Math, 118, pp. 1-17.

[8] A. H Shah, A. Hassan, M. S. Laghari, A. Alraeesi. 2020. The Influence of Cleaning Frequency of Photovoltaic Modules on Power Losses in the Desert Climate. Sustainability, 12(22), 9750.
[9] Y. Zhou, J. Xin. 2020. Dust removal device for waterless solar photovoltaic panel. In IOP Conference Series: Earth and Environmental Science (Vol. 514, No. 4, p. 042032). IOP Publishing.

[10] Z. Fan, M. Wang, J. Mu, J..Yi. 2020. Alternative cleaning and dust detection method for PV modules and its application. Journal of Renewable and Sustainable Energy, 12(5), 053503.

[11] M. Z Al-Badra, M. S. Abd-Elhady, H. A Kandil. 2020. A novel technique for cleaning PV panels using antistatic coating with a mechanical vibrator. Energy Reports, 6, 1633-1637. 